\title{
Systematic position and habitat distribution modelling for reintroduction of critically endangered medicinal plant Pittosporum eriocarpum Royle (Pittosporaceae)
}

\author{
Mayank D. Dwivedi ${ }^{1 \#}$, Sandeep Chauhan ${ }^{1}$, Amber Srivastava ${ }^{2}$, Pragya \\ Sourabh $^{3}$, Shivani Mishra ${ }^{3,4}$, Julie Thakur ${ }^{5}$ and Achuta Nand Shukla ${ }^{6}$ \\ ${ }^{1}$ Botanic Garden of Indian Republic, Botanical Survey of India, Capt. Vijayant Thapar Marg, Noida \\ 201303, Uttar Pradesh, India; ${ }^{2}$ Northern Regional Centre, Botanical Survey of India, Kaulagarh Road, \\ Dehradun 248006, Uttrakhand, India; ${ }^{3}$ Faculty of Life Science, Mansarovar Global University, Bilkisganj, \\ Sehore 466001, Madhya Pradesh, India; ${ }^{4}$ Food Corporation of India, Delhi-110007, India; \\ ${ }^{5}$ Bhaskaracharya College of Applied Science, Dwarka, Delhi-110075, India; ${ }^{6}$ Central Regional Centre, \\ Allahabad 211001, Uttar Pradesh, India. \\ \#Communicating author, e-mail: mayank_dwivedi10@yahoo.com
}

[Received 12.05.2020; Revised 22.06.2020; Accepted 26.06.2020; Published 30.06.2020]

\begin{abstract}
Pittosporum eriocarpum Royle (Pittosporaceae) is an endemic and endangered species of Indian Western Himalaya which is found in the restricted pockets of Uttarakhand and Himachal Pradesh only. The species is facing critical threats on its natural population mainly due to habitat loss, climate change and other anthropogenic activities. In order to improve the conservation status of species, potential suitable habitats for reintroduction, were predicted using Maxent. The species shows high variability in its morphological characteristics due to which sometimes it is being confused with other allied species $P$. napaulense and to avoid future confusion, systematic position of the species has been ascertained using nrDNA Internal Transcribed Spacer sequence data.
\end{abstract}

Key words: - nrDNA ITS, ML, ENM, Endangered

\section{INTRODUCTION}

The genus Pittosporum Banks ex Gaertn. (Pittosporaceae)is represented by ca.240 species occurring in different tropical regions of the world (Carolin \& Bittrich 2018; Chandler et al. 2007), many of which are introduced for horticultural purposes. In India, the genus is represented by 11 species distributed in the Himalayas and in Western Ghats. Of these, only two species vi\%. P. eriocarpum Royle and P. napaulense (DC.) Rehder \& E.H. Wilson are reported to occur naturally in North-West Himalaya (Nayar \& Giri 1993). Pittosporum eriocarpum is endemic to Indian Western Himalaya and so far reported from the states of Himachal Pradesh and Uttarakhand. The species was first described by J.F. Royle from the upper hills of Sahastradhara and Mussoorie (Royle 1834). The species was considered endemic to Uttarakhand Himalaya from the range between Jumna (=Yamuna) to Sarda valley (Hooker \& Thomson 1872; Brandis 1874; Gamble 1902; Brandis 1906). Parker (1918) reported it from, then called Suket state, Kangra district (now in Mandi district) of Himachal Pradesh. Somehow it remained unnoticed and the species was considered as endemic to Uttarakhand only (Hajra 1983; Nayar \& Sastry 1987; Nayar 1996; Gaur 1999; Pullaiah 2006; Singh et al. 2015). The species has been reported from a few localities of Uttarakhand viz: Mussoorie, JhariPani, HathiPaon, Kempty Range, Nagni, Dhaulagiri, Sahastradhara, Nainital etc. (Kanjilal 1928; Hajra 1983; Gaur 1999; Pundir 2014). 
110 Systematic position and distribution modelling of Pittosporum eriocarpus

The species shows high variability in its morphology due to which sometimes it is being confused with other allied species $P$. napaulense hence to avoid future confusion systematic position of the species has been ascertained using nrDNA ITS phylogeny.

The habitat area of Pittosporum eriocarpum has been depleted mostly due to habitat fragmentation, over-exploitation, increasing human population and demand of land for cultivation and other economic development activities (Pragya et al. 2018). It is, therefore, necessary to get detailed information on potential suitable habitats for the reintroduction as measure for conservation of this medicinally important plant. Habitat distribution modelling helps to identify the suitable areas for reintroduction and in developing effective species conservation strategies.

\section{MATERIAL AND METHODS}

Morphology : Different floristic explorations during 2012 to 2019 to Western Himalayas several specimens of $P$. eriocarpum were collected for ex-situ conservation, mass propagation and further in-situ conservation. The study of the vegetative as well as flowering stages of the collected plants revealed its close resemblance to $P$. napaulense and is critically endangered due to its overharvesting for medicinal uses.

Sampling : Four accessions of P. eriocarpum were collected from different localities in Uttarakhand (Table 1). Young leaves preserved in silica gel was used for molecular work. The Sanger sequences generated were added to a dataset comprising of 62 species of Pittosporum downloaded from GenBank including outgroups. The sequence alignment is available from the authors on request.

Table 1. Species, source and GenBank accession number for the DNA accessions used in the present study. Taxa sequenced for ITS region of Nuclear DNA

\begin{tabular}{|l|l|l|}
\hline \multicolumn{1}{|c|}{ Taxon } & \multicolumn{1}{|c|}{ Locality } & \multicolumn{1}{c|}{$\begin{array}{c}\text { GenBank accession } \\
\text { number }\end{array}$} \\
\hline $\begin{array}{l}\text { Auranticarpa edentate L.W. Cayzer, Crisp \& I. } \\
\text { Telford }\end{array}$ & Australia & AY829013 \\
\hline A. licifolia L.W.Cayzer, Crisp \& I.R.H.Telfor & Australia & AY829014 \\
\hline Billardiera lehmanniana F.Muell. & Australia & AY829020 \\
\hline B. longiflora Labill. & Australia & AY829021 \\
\hline Bursaria incana Lindl. & Australia & AY829023 \\
\hline B. spinose Cav. & Australia & AY829024 \\
\hline Griselinia jodinifolia (Griseb.) Taub. & Chile: Valdivia prov. & AJ536580 \\
\hline G. racemosa (Phil.) Taub. & Chile: Chiloe prov. & AJ536583 \\
\hline G. scandens (Ruiz \& Pav.) Taub. & Chile & AJ536586 \\
\hline Hymenosporum flavum F.Muell. & Australia & AY829026 \\
\hline Marianthus bicolor (Putt.) F. Muell. & Australia & AY829028 \\
\hline M. ringens (J. Drumm. ex Harv.) F. Muell. & Australia & AY829027 \\
\hline Rhytidosporum alpinum McGill. & Australia & AY829045 \\
\hline P. angustifolium Lodd. & Australia & AY829029 \\
\hline P. angustifolium & Australia & HM116993 \\
\hline P. arborescens & Cook Island, Rarotonga & AF302025 \\
\hline P. arborescens Rich ex. A. Gray & Kingdom of Tonga, Vava'u & AF302026 \\
\hline P. balfouri Cufod. & Mauritius & AF302015 \\
\hline
\end{tabular}


Mayank D. Dwivedi et al. 111

\begin{tabular}{|c|c|c|}
\hline Taxon & Locality & $\begin{array}{c}\text { GenBank accession } \\
\text { number }\end{array}$ \\
\hline P. bracteolatum & Australia & \\
\hline P. coccineum Beauvis. & New Caledonia, Poya & AF302033 \\
\hline P. cornifolium A. Cunn. & New Zealand, cultivated & AF302030 \\
\hline P. crassifolium Banks \& Sol. ex A. Cunn. & New Zealand & EF635471 \\
\hline P. dallii Cheeseman & $\begin{array}{l}\text { Kahurangi National Park, } \\
\text { New Zealand }\end{array}$ & U63196 \\
\hline P. eriocarpum Royle & Nainital, Uttrakhand, India & GB Acc. No. awaited \\
\hline P. eriocarpum & Gangolihat, Uttrakhand, India & GB Acc. No. awaited \\
\hline P. eriocarpum & $\begin{array}{l}\text { Sahastradhara, Uttrakhand, } \\
\text { India }\end{array}$ & GB Acc. No. awaited \\
\hline P. eriocarpum & Mussoorie, Uttrakhand, India & GB Acc. No. awaited \\
\hline P. fairchildii Cheeseman & $\begin{array}{l}\text { New Zealand: Three Kings } \\
\text { Islands }\end{array}$ & EF635472 \\
\hline P. ferrugineum W.T. Aiton & Australia & AY829032 \\
\hline P. gatopense Guillaumin & New Caledonia, Poya & AF302034 \\
\hline P. glabratum Lindl. & $\begin{array}{l}\text { China: Dinghushan National } \\
\text { Nature Reserve }\end{array}$ & KP092543 \\
\hline P. glabratum Lindl. & $\begin{array}{l}\text { China: Dinghushan National } \\
\text { Nature Reserve }\end{array}$ & KP092542 \\
\hline P. illicioides Makino & $\begin{array}{l}\text { China: Hualong Mountain in } \\
\text { Daba Mountains Range }\end{array}$ & MH710957 \\
\hline P. illicioides Makino & China & JX106283 \\
\hline P. Koghiense Guillaumin & New Caledonica, Mt. Dmuzac & AF302035 \\
\hline $\begin{array}{l}\text { P. lancifolium (F.M. Bailey) L.W. Cayzer, } \\
\text { Crisp \& I.Telford }\end{array}$ & Australia & AY829033 \\
\hline P. phillyraeoides DC. (=P. ligustrifolium) & Australia & AY829034 \\
\hline P. mannii Hook.f. & Kenya & MK696153 \\
\hline P. moluccanum Miq. & Australia & AY829035 \\
\hline $\begin{array}{l}\text { P. multiflorum (A.Cunn. ex Loudon) L.W. } \\
\text { Cayzer, Crisp \& I. Telford }\end{array}$ & Australia & AY829036 \\
\hline P. oreillyanum C.T. White & Australia & AY829037 \\
\hline P. podocarpum Gagnep. & $\begin{array}{l}\text { China: Hualong Mountain in } \\
\text { Daba Mountains Range }\end{array}$ & MH710978 \\
\hline P. ralphii Kirk & New Zealand & EF635473 \\
\hline P. ramiflorum Zoll. ex Miq. & Papua New Guinea & DQ499124 \\
\hline P. resiniferum Hemsl. & Philippines and Malaysia & DQ007353 \\
\hline P. revolutum Aiton & Illinois, USA & AY829038 \\
\hline P. rubiginosum A. Cunn. & Australia & AY829039 \\
\hline $\begin{array}{l}\text { P. spinescens (F.Muell.) L.W.Cayzer, Crisp \& } \\
\text { I.Telford }\end{array}$ & Australia & AY829040 \\
\hline P. taitense Putterl. & Society Island, Bota Bora & AF302027 \\
\hline P. tenuifolium subsp colensoi & New Zealand & DQ499125 \\
\hline P. truncatum E. Pritz. & $\begin{array}{l}\text { China: Qinling Mountains } \\
\text { Range }\end{array}$ & MH710783 \\
\hline
\end{tabular}


112 Systematic position and distribution modelling of Pittosporum eriocarpus

\begin{tabular}{|l|l|l|}
\hline \multicolumn{1}{|c|}{ Taxon } & \multicolumn{1}{c|}{ Locality } & \multicolumn{1}{c|}{$\begin{array}{c}\text { GenBank accession } \\
\text { number }\end{array}$} \\
\hline P. truncatum E. Pritz. & $\begin{array}{l}\text { China: Qinling Mountains } \\
\text { Range }\end{array}$ & MH711550 \\
\hline P. truncatum E. Pritz. & $\begin{array}{l}\text { China: Qinling Mountains } \\
\text { Range }\end{array}$ & MH710692 \\
\hline P. undulatum Guill. & Australia & AF302014 \\
\hline P. undulatum Guill. & Australia & HM116994 \\
\hline P. venulosum F. Muell. & Australia & AY829043 \\
\hline
\end{tabular}

Molecular analyses: Genomic DNA was extracted from silica dried materials using a Dneasy Plant Mini Kit (Qiagen, Amsterdam, Netherlands). DNA amplification and sequencing of the entire ITS region (ITS1,5.8S and ITS2) were performed using the primers ITS1 and ITS4 (White et al. 1990). The polymerase chain reaction (PCR) was performed with standard methods using RedDye Master mix $(12.5 \mu \mathrm{l})$ and PCR amplification was performed with 35 cycles (Denaturation for $1 \mathrm{~min}$ at $94^{\circ} \mathrm{C}$, annealing for $1 \mathrm{~min}$ at $49^{\circ} \mathrm{C}$, and $1 \mathrm{~min}$ of extension at $72^{\circ} \mathrm{C}$ followed by a last cycle of final extension for $5 \mathrm{~min}$ at $72^{\circ} \mathrm{C}$ ). PCR products were checked for the presence of appropriate bands on a $0.8 \%$ agarose gel, purified, and sequenced at $1 \mathrm{~B}$ ase Labs., South Korea. Forward and reverse sequences were edited and assembled using the computer program and DNA Baser vers. 4 (2013, Heracle Biosoft). All sequences have been deposited in GenBank.

Phylogenetic Analyses: Maximum Likelihood (ML) performed after determining the models of evolution selected in jModelTest v.2.1.5 (Darriba et al. 2012) by Akaike test (option AIC), ML analyses was performed at CIPRESS Science gateway (Miller et al. 2010). Maximum Likelihood analyses were performed using RAxML-HPC2 on XSEDE ver. 8.2.12 (Stamatakis 2014) on the gateway. RAxML was run under the model selected from the jModel test with 20 heuristic searches from distinct random stepwise addition sequence parsimony starting trees, followed by selection of best scoring tree. RAxML bootstrap (BS) values were calculated using 1000replicates. The outgroups were selected from previous studies (Chandler et al. 2007).

Species distribution modelling and future prediction : For the analysis 60 primary distributional records of the species were used which were obtained through field surveys. The coordinates of all the occurrence points were recorded to an accuracy of $3-10 \mathrm{~m}$ using GPS (Garmin). These coordinates were then converted to decimal degrees for use in modelling the distribution of habitats of the species. Bioclimatic variables (Hijmans et al. 2005) with 30 seconds spatial resolution, downloaded from World Clim dataset (www.worldclim.org) were used in the present study. These World Clim data (period 1950 - 2000) are derived from measurements of altitude, temperature and rainfall from weather stations across the globe (Khanum et al. 2013) and are frequently used in modelling species distribution (Kumar \& Stoghlgren 2009; Sanchez et al. 2011; Khanum et al. 2013; Adhikari et al. 2015).

For habitat modelling, the model was developed using Maximum entropy distribution software (Maxent version 3.3.3; Phillips et al. 2006; http:/ /www.cs.princeton.edu/wschapire), which generates an estimate of probability of the presence of species that varies from 0 to 1 , where 0 is the lowest and 1 is the highest probability. Of the 60 records, seventy five percent were used for model training and twenty five percent for testing. To validate the model robustness, 10 replicated models runs for the species with a threshold rule of 10 percentile training presence was executed. In the replicated runs, cross validation technique was employed, where samples were divided into replicate folds and each fold was used for test data. Other parameters were 
set to default as the program is already calibrated on a wide range of species datasets (Phillips $\&$ Dudík 2008). From the replicated runs average, maximum, minimum, median and standard deviation were generated. Jackknife procedure and percent variable contributions were used to estimate the relative influence of different predictor variables. Receiver operating characteristics (ROC) analyses the performance of a model at all possible threshold by a single number called, the area under the curve (AUC).. Higher AUC values correspond to better model quality and accuracy. The Area under the ROC curve (AUC) was used to evaluate model performance. AUC is a measure of model performance and varies from 0 to 1 (Fielding \& Bell 1997). An AUC value of 0.50 indicates that model did not perform better than random whereas a value of 1.0 indicates perfect discrimination (Swets 1988). Future climate scenario data for 2050 (A2a emission scenario) were obtained from Consultative Group on International Agricultural Research (CGIAR). (http://ccafsclimate.org). These future climate projections are based on IPCC $4^{\text {th }}$ assessment data and were calibrated and statistically downscaled using the data for 'current' conditions.

\section{Sequence analyses}

\section{RESULTS}

For the study a total of 62 sequences were analyzed of which four accessions (GenBank accession number [MT677940, MT677941, MT677942, MT677943, submitted]) have been newly generated from P. eriocarpum collected from different localities of Uttarakhand [Western Himalaya]. This is the first study to have analyzed any Indian species of Pittosporum.

\section{Multiple sequence alignment}

The alignments of the ITS regions (ITS1, 5.8s ITS2) consists of 715 characters; $8.5 \%$ of which are gaps; GC content is $61.6 \%$; 298 identical sites represent $41.7 \%$; pairwise percentage identity is $89.4 \%$; parsimonious informative sites are 257 . Final alignment has been be submitted to TreeBASE also can be obtained from corresponding author on request.

\section{Evolutionary model estimation}

The best fit model according to BIC criterion is TNe $+\mathrm{G} 4$ as evaluated in jModeltest (Dariba $2 \mathrm{t}$ al 2012). Model selected implemented as -f parameter for subsequent phylogenetic analyses. The rate parameters were - A-C: 1.000; A-G: 3. 1690; A-T: 1.000; C-G: 1.000; C-T: 6.8834; and G-T: 1.000 .

\section{ML phylogenetic analyses}

The tree topology retrieved (Figure 1) has similar topology to that from the previous studies (see Chandler et al. 2007). The log-likelihood of the tree is -5605.384. The total tree length i.e. sum of all branch length is 1.5651. Sum of internal branch length is 0.6297. All the species of Pittosporum after originating from the last common ancestor grouping in single clade. Four accessions of Indian species of P. eriocarpum (BP 100) is placed along P. balfauri and P. mannii (BP. 75).

\section{Taxonomic description}

Shrubs or small trees, $4-8 \mathrm{~m}$ tall. Bark grayish brown, somewhat rough, young shoots and branchlets densely tomentose, glabrous later. Leaves simple, exstipulate, alternate or falsely whorled usually clustered towards the tips of branchlets; lamina obovate to oblanceolate to elliptic-oblong, $4-12 \times 2-5 \mathrm{~cm}$, entire, acuminate or acute, sometimes mucronate, base cuneate, membranous, lateral veins about 12-16 on each side, midrib impressed above and slightly prominent beneath, transversely horizontal; petiole $15-20 \mathrm{~mm}$ long, tomentose. Inflorescence terminal or pseudoterminal, paniculately corymbose, glabrous; peduncles $2-4 \mathrm{~cm}$ long; pedicels 
5 - $8 \mathrm{~mm}$ long, Flowers bisexual, buds oblong, 6 - $9 \mathrm{~mm}$ across; sepals 5, subequal, lanceolateovate, $2 \times 1 \mathrm{~mm}$, margins minutely ciliate, subacute, minutely pilose; petals 5 , usually ligulate, linear oblong, $9-10 \times 2-2.5 \mathrm{~mm}$, obtuse, pal yellow; -stamens 5, free, alternate to petals; filaments slender, glabrous, about $5 \mathrm{~mm}$ long; anthers sagittate, dorsifixed, oblong, $2-2.5 \mathrm{~mm}$ long; ovary superior, ovoid, densely brown-tomentose, about $2 \mathrm{~mm}$ across. Capsules sub-globose, transversely ribbed, 12 - $15 \mathrm{~mm}$ across, pericarp hard woody, densely pilose-tomentose, dehiscing with $2-5$ valves; seeds many, oblong-ovoid, irregularly compressed, embedded with glutinous, resinous pulp, reddish-black.

\section{Distribution}

Endemic to Indian Western Himalaya. Reported only from Uttarakhand and Himachal Pradesh from an altitudinal range of 900-2000 m.

\section{Morphological variations}

The species shows different types of variations in both vegetative and flowering characteristics with response to changes in environmental and habitat conditions.

a. Growth habit: variations have been observed in its growth pattern in different habitats. While growing on rocky slopes plants are shorter and bushier, whereas when growing on gentle slopes or planted in plain land it become straight and attains good height

b. Shape of lamina: In vegetative state, the shape of lamina varies from ovate or obovate to lanceolate even on a single branch. In some populations, the leaves are broader becoming slightly ovate whereas it is lanceolate in other populations.

c. Flowering and Fruiting: The flowers of this species are heterostylous having variations in size and functionality of stamens and stigma. Some of the plants bears functional female flowers having fertile stigma but sterile stamens whereas some trees produce only functionally male flowers having well developed and fertile stamens but underdeveloped stigma. Some plants also behave as sexually labile and behaves as either male or female in different years. However, sometimes fruit set is also seen in functionally male flowers due to leaky dioecism (Das et al. 2017).

Variations are also observed in shape and size of fruits in some habitats. The fruits collected from Sahastradhara were somewhat angular. Also, the thickness of fruit valves (pericarp) varied in fruits collected from planted trees in GBPNIHESD, Kullu with that of other populations in Uttarakhand. The fruit valves of former plants were thin as compared to fruits of other localities which may be due to variable responses to climatic conditions prevailing in those localities.

In light of the above morphological variations sometimes the species shows overlapping characteristics with its allied species $P$. napaulense thus leading to misidentification (Srivastava et al. 2017).

\section{Molecular diagnosis}

Accessions of P. eriocarpum differs at several positions from $P$. balfourizin ITS alignment with its related species: position $81 \mathrm{G} / \mathrm{A}, 89 \mathrm{~T} / \mathrm{C}, 100$ \& $101 \mathrm{CC} / \mathrm{GT}, 138-140$ TTG/CTT, $185 \mathrm{C} / \mathrm{T}$, 193 A/G, 203 T/C, 217 C/T, 227 A/G, 233 A/G, 382 T/C, 399 C/T, 421 - 423 GTT/ACC

\section{Potential suitable habitat for reintroduction}

The maxent model for $P$. eriocarpum performed well with an average AUC value of 0.998 . Most suitable habitat is predicted in Uttarakhand, India with an area of $9084 \mathrm{~km}^{2}$ of high suitability and $6040 \mathrm{~km}^{2}$ as very highly suitable (Figure $2 \mathrm{a} \& 3 \mathrm{a}$ ). Table 2 shows the relative contributions of the predictor variables in Maxent for distribution of P. eriocarpum. Precipitation of Driest 


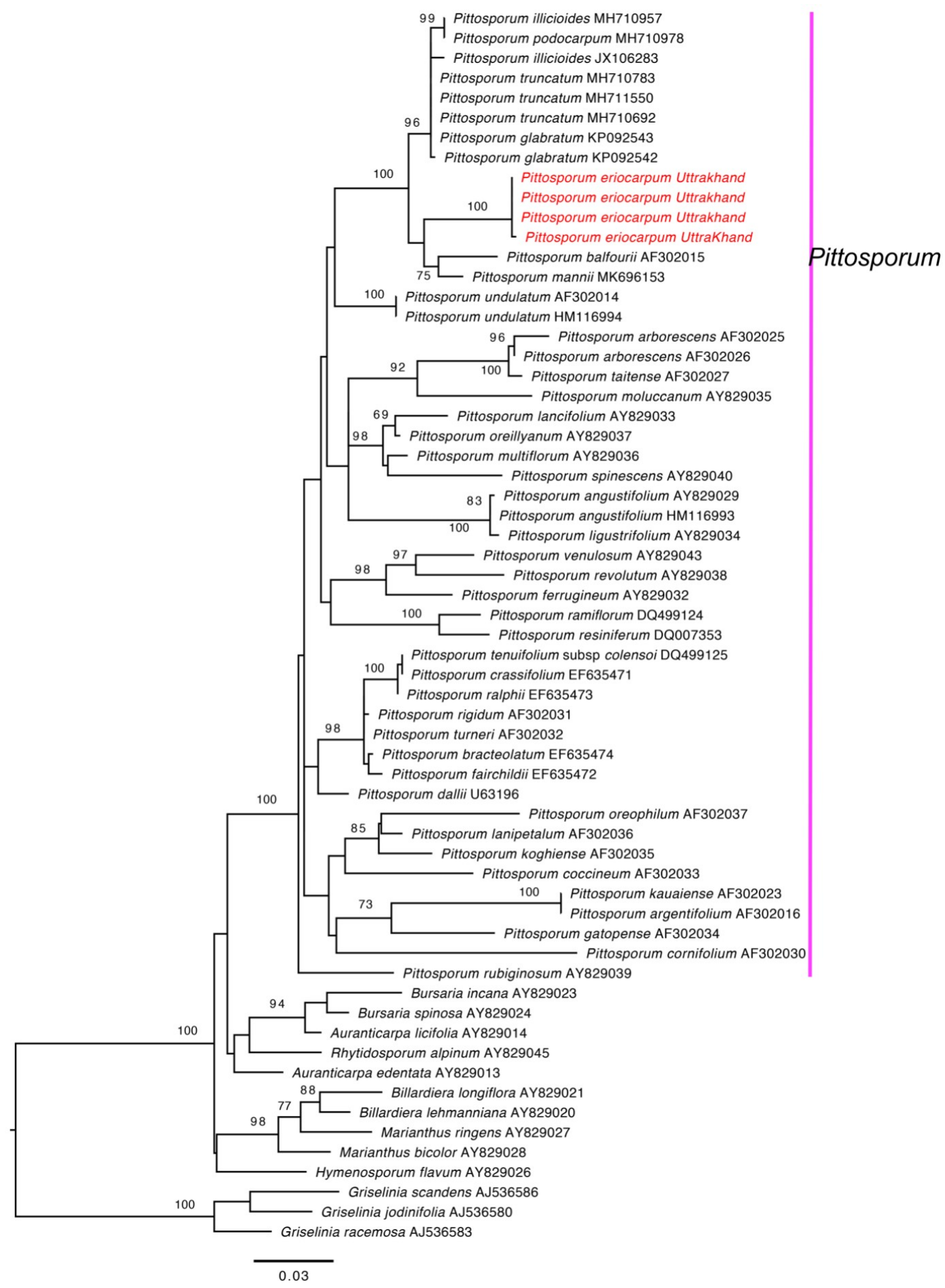

Figure 1. Best maximum likelihood phylogeny based on the nrDNA ITS data (724 base pairs). Likelihood bootstrap values $>70$ shown at the nodes Pittosporum eriocarpum highlighted in red, for GB-sequence accession number provided from GB (downloaded from GenBank.) 
Quarter (Bio 17), Precipitation Seasonality (Bio 15), Precipitation of Warmest Quarter (Bio 18) and Mean Temperature of Coldest Quarter (Bio 11) were the strongest predictors for the distribution of P. eriocarpum with $59.2 \%, 18.7 \%, 11.1 \%$ and $5.6 \%$ contributions, respectively. The probability of presence of $P$. eriocarpum increased with an increase in precipitation of driest quarter and precipitation seasonality (Figure $3 \mathrm{a}, \mathrm{b}$ ). Relative importance of different environmental variables based on results of jackknife tests in Maxent are shown in Figure 4. Jackknife results also showed that Precipitation of Driest Quarter is the most important predictor for the distribution of P. eriocarpum.

Table 2:Selected environmental variables and their percent contribution in maxent model for P. eriocarpum

\section{Environment Variables}

Precipitation of Driest Quarter (Bio 17)

Precipitation Seasonality (Bio 15)

Precipitation of Warmest Quarter (Bio 18)

Mean Temperature of Coldest Quarter (Bio 11)

Precipitation of Wettest Quarter (Bio 16)

Precipitation of Coldest Quarter (Bio19)

Minimum Temperature of Coldest Month (Bio 6)

Mean Temperature of Driest Quarter (Bio 9)

\section{Percent Contribution}

59.2

18.7

11.1

5.6

2.3

1.4

0.9

0.7
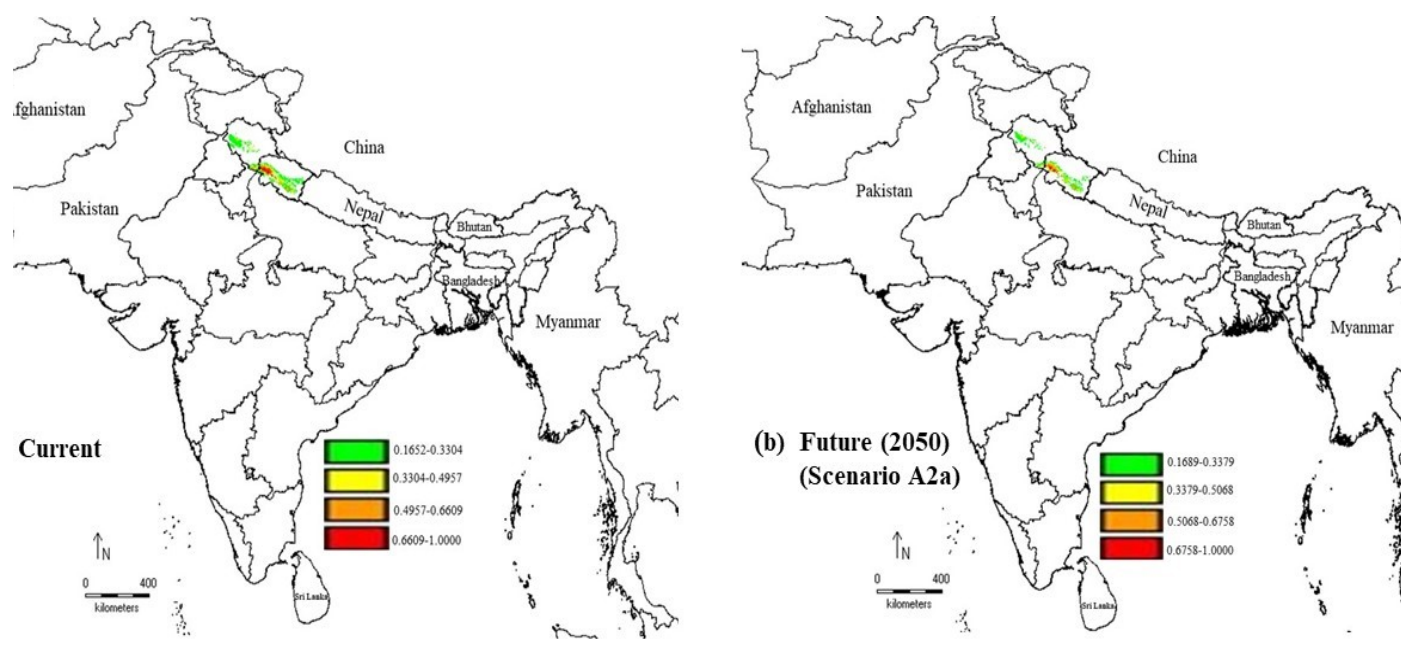

Figure 2. Predicted current and future potential suitable habitat of P. eriocarpum in India

Compared with the area of most suitable habitat $\left(6040 \mathrm{~km}^{2}\right)$ under current climate prediction, the future prediction model for 2050 (A2a emission scenario) showed loss of habitat (Figure 1b), with the most optimal geographic distribution of $3023 \mathrm{~km}^{2}$ (Figure 2b). Although the location of future potential distribution of P. eriocarpum is very similar to the current potential distribution, the model results suggest that there is a significant loss of very highly suitable habitat of $50.04 \%$ area. 


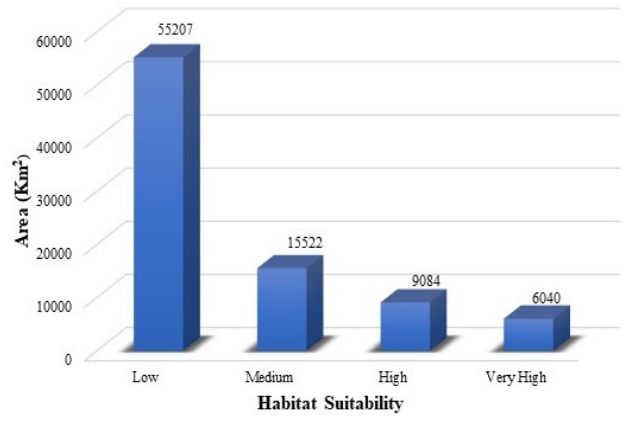

(a) Current

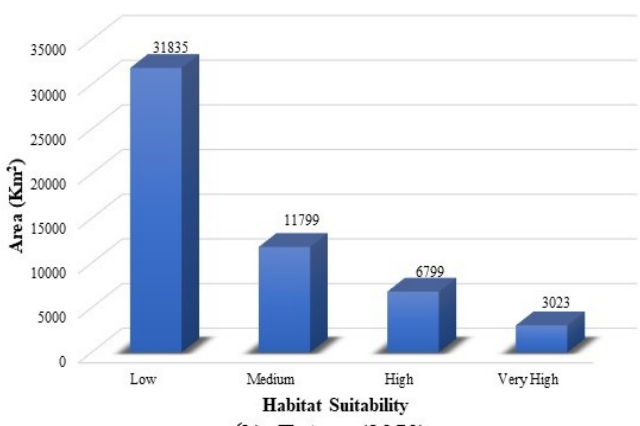

(b) Future (2050)

(Scenario A2a)

Figure 3. Area under different suitability grades for current and future potential suitable habitat of P. eriocarpum in India. Figures at the top of each bar represent the area
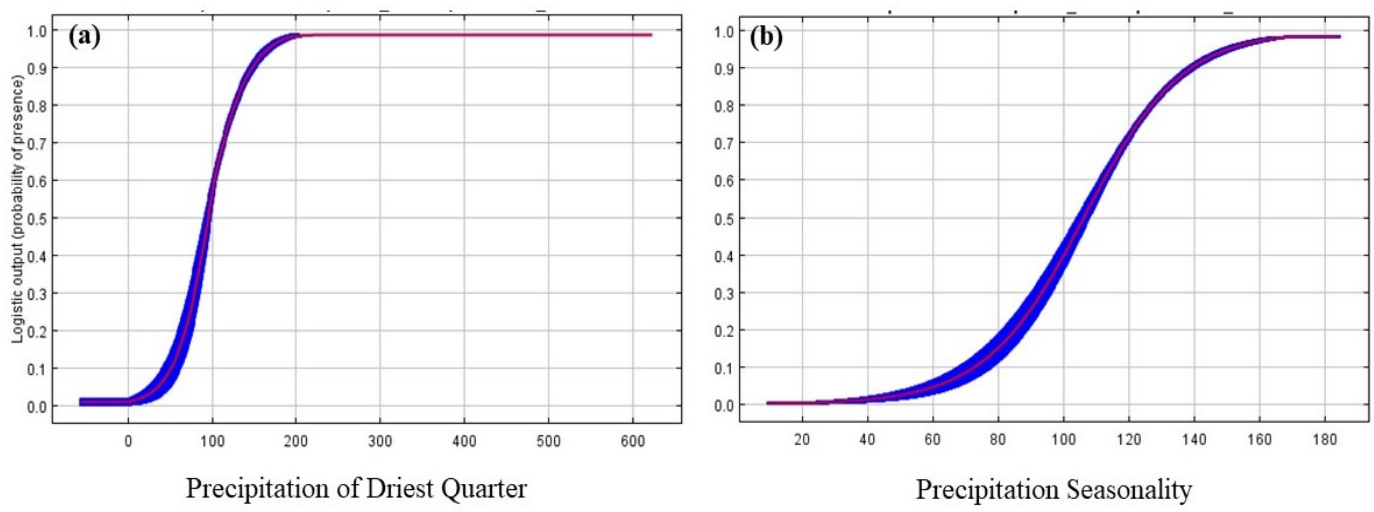

Figure 4. Response curves showing relationships between probability of presence of a species and two top bioclimatic predictors of P. eriocarpum $(\mathrm{a}, \mathrm{b})$

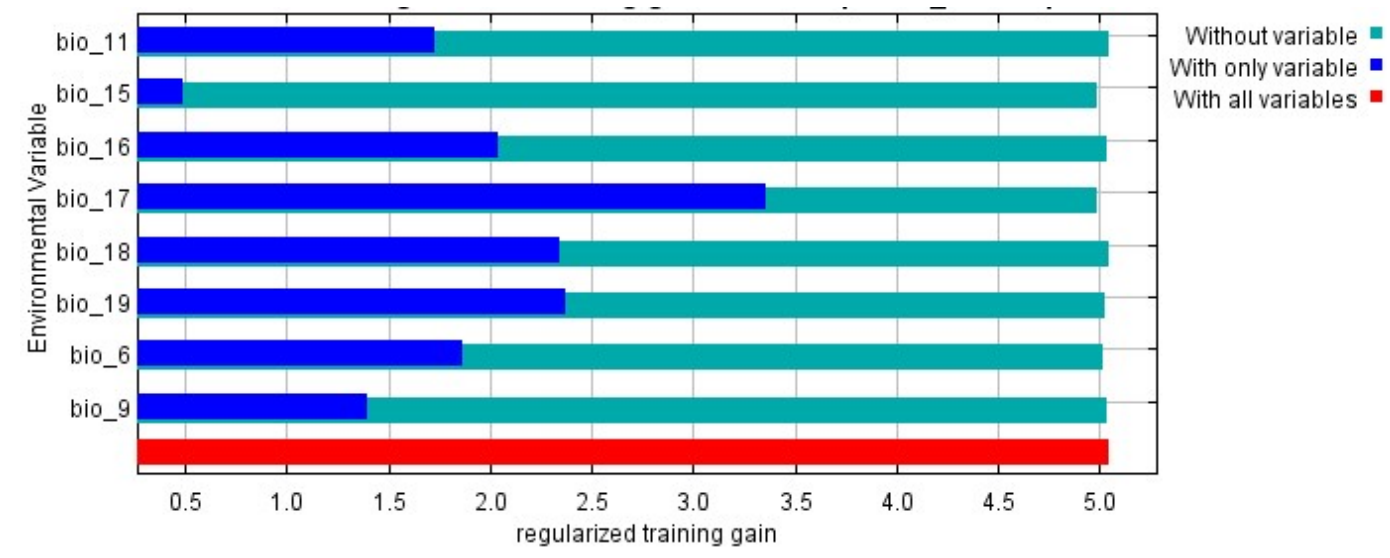

Figure 5. Relative predictive power of different bioclimatic variables based on the jackknife of regularized training gain in maxent model for $P$. eriocarpum 
118 Systematic position and distribution modelling of Pittosporum eriocarpus

\section{DISCUSSION AND CONCLUSION}

The ML analyses showed the monophyletic nature of the genus Pittosporum Banks ex Gaertn. of Pittosporaceae. Species of Pittosporum are found to be grouping in well supported (BP 100 Figure 1) clade and supports the previous study by Chandler et al. (2007). Pittosporum eriocarpum collected from Uttrakhand (Western Himalaya) is placed within the monophyletic clade. Systematic position of Indian P. eriocarpum is very interesting due to its placement along with $P$. balfourii from Mauritius. The best explanation for the placement could be the Gondwanan origin of P. balfourii (Gemmill et al. 2002). The ITS sequence data has ascertained the systematic position of the species, morphological description provided in the present communication binds with the molecular data and will help taxonomists, biochemists and ecologists to identify, eradicate adulterants and the ENM data generated (Figure 2) will be helpful for conservation biologists. The ENM data reveals the most suitable habitat for Pittosporum eriocarpum is predicted in Western Himalaya. The model results showed that $7.03 \%$ of the total predicted area is highly potential. In regard to future distribution of $P$. eriocarpum, the modelling suggests that its geographic distribution would shrink. The restricted distribution of highly suitable habitats of P. eriocarpum in Western Himalaya suggests that the plant is endemic to Western Himalayan region of India, which has also been suggested through previous field surveys, herbarium records and literature (Padalia et al. 2010). The zone mapped in the study with higher model thresholds suggests that these areas have ideal habitat conditions for reintroduction of the $P$. eriocarpum. The current and predicted map of suitable habitat and identification of suitable bioclimatic variables can be of significant use for government and non-government organizations responsible for management and conservation of threatened medicinal plants (Malay et al. 2018).

\section{Acknowledgements}

Authors are thankful to the Director, Botanical Survey of India for all sorts support and facilities; The Ministry of Environment, Forest and Climate Change (MoEF\& CC), Government of India, New Delhi has provided financial support to this study (Project GBPNI/NMHS 2017 18/LG 03/570dt.26/02/2018). They sincerely express their gratitude to Prof. Arun K. Pandey, Vice-Chancellor, Mansarovar Global University, Bhopal for his continuous encouragements during our research work and his constructive comments on the MS.

\section{LITERATURE CITED}

Adhikari, D. Tiwary, R. \& Barik, S.K. 2015. Modelling Hotspots for Invasive Alien Plants in India. PLOS ONE 10(7): e0134665.

Brandis, D. 1874. The Forest Flora of North-West and Central India. Rep. 1972. Bishen Singh Mahendra Pal Singh, Dehradun.

Brandis, D. 1906. Indian Trees. Rep. 2003. Bishen Singh Mahendra Pal Singh, Dehradun

Carolin, R.C., Bittrich, V. 2018. Pittosporaceae, in: Kadereit, J.W. \& Bittrich, V. (eds.), Flowering Plants. Eudicots, The Families and Genera of Vascular Plants 15. Springer International Publishing AG., Cham, pp. 539-547.

Chandler, G.T., Gregory, M.P., Steven, M.P., Lindy, W.C., Chrissen, E.C.G. 2007. Molecular and morphological agreement in Pittosporaceae/ : phylogenetic analysis with nuclear ITS and plastid trn $\mathrm{L}-\operatorname{trn} \mathrm{F}$ sequence data. Aust. Syst. Bot. 29, 390-401. 
Darriba D, Taboada GL, Doallo R, Posada D. 2012. jModelTest 2: more models, new heuristics and parallel computing. Nature Methods 9(8): 772

Das, K., Tandon, R., Bhatnagar, A.K. 2017. Standardization of pollen germination medium for Pittosporum eriocarpum - an endemic, endangered tree species of Central and Western Himalayas. Int. J. Plant Repro. Biol. 9: 77-81. https://doi.org/10.14787/ijprb.2017

DNA Sequence Assembler ver 4 .2013, Heracle BioSoft, www.DnaBaser.com.

Fielding, A.H. \& Bell, J.F. 1997. A review of methods for the assessment of prediction errors in conservation presence/ absence models. Environmental Conservation 24: 38-49.

Gamble, J.S. 1902. A Manual of Indian Timbers. Rep. 1972. Bishen Singh Mahendra Pal Singh, Dehradun.

Gemmill, C.E.C., Allan, G.J., Wagner, W.L., Zimmer, E.A. 2002. Evolution of insular pacific Pittosporum (Pittosporaceae): Origin of the Hawaiian radiation. Mol. Phylogenet. Evol. 22: 31-42. https://doi.org/10.1006/mpev.2001.1019

Hajra, P.K. 1983. Plants of Northwest Himalaya with restricted distribution - A census. In: S.K. Jain \& R.R. Rao (eds.), An Assessment of Threatened Plants of India. Botanical Survey of India, Howrah.

Hijmans, R.J.; Cameron, S.E.; Parra, J.L.; Jones, P.G. \& Jarvis, A. 2005. Very high-resolution interpolated climate surface for global land areas. Int J Climatol 25: 1965-2198.

Hooker, F. \& Thomson .1872. Pittosporum. In: Flora of India. Hooker, J.D. (eds.). L. Reeve \& Co., London.

Kanjilal, U. 1928. Forest Flora of the Chakrata, Dehradun and Saharanpur forest Divisions, Rep. 1994. Bishen Singh Mahendra Pal Singh, Dehradun

Khanum, R.; Mumtaz, A.S. \& Kumar, S. 2013. Predicting impacts of climate change on medicinal asclepiads of Pakistan using Maxent modelling. ActaOecol 49: 23-31.

Kumar, S. \& Stohlgren, T.J. 2009. Maxent modelling for predicting suitable habitat for threatened and endangered tree Canacomyrica monticola in New Caledonia. J Ecol 1(4): 94-98.

Malay, P. Uttam, P. Biswajit M., Suman C. \& Pratik D. 2018. Predicting climate change impacts on the distribution of the threatened Garcinia indica in the Western Ghats, India. Climate Risk Management. 19: 94-105

Miller, M.A., Pfeiffer, W. \& Schwartz, T. 2010. Creating the CIPRES Science Gateway for inference of large phylogenetic trees. In: IEEE (ed.) Proceedings of the Gateway Computing Environments Workshop (GCE), 14 Nov. 2010. New Orleans, LA, pp. 1-8. http://dx.doi.org/10.1109/GCE.2010.5676129

Nayar, M.P. \& Giri, G.S. 1993. Pittosporaceae. In: Sharma, B.D. \& Balakrishnan, N.P. (eds.) Flora of India, Vol. 2. Botanical Survey of India, Calcutta

Nayar, M.P. \& Sastry, A.R.K. 1987. Red Data Book of Indian Plants. Vol. 1. Botanical Survey of India, Calcutta

Nayar, M.P. 1996. Hot Spots of Endemic Plants of India, Nepal and Bhutan. Tropical Botanical Garden and Research Institute, Thiruvananthapuram, India.

Padalia, H.; Bharti, R.R.; Pundir, Y.P.S. \& Sharma, K.P. 2010. Geospatial multiple logistic regression approach for habitat characterization of scarce plant population: A case study of Pittosporum eriocarpum Royle (an endemic species of Uttarakhand, India). J Indian Soc Remote 38(3): 513-521.

Parker, R.N. (1918). A Forest Flora for the Punjab with Hazara and Delhi. Rep. 1984. Bishen Singh Mahendra Pal Singh, Dehra Dun. 
120 Systematic position and distribution modelling of Pittosporum eriocarpus

Phillips, S.J.; Anderson, R.P. \& Schapire, R.E. 2006. Maximum entropy modelling of species geographic distributions. Ecological Modelling 190: 231-259.

Pullaiah, T. 2006. Encyclopaedia of World Medicinal Plants. Regency Publications, New Delhi.

Pundir, Y.P.S. 2014. Is Pittosporum eriocarpum Royle endangered Creative Grove.

Royle, J.F. 1834. Illustrations of the Botany and Other Branches of the Natural History of the Himalayan Mountains: and of the flora of Cashmere. Vol. 1. Wm. H. Allen, London.

Sanchez, A.C.; Osborne, P.E. \& Haq, N. 2011. Climate change and the African baobab (Adansonia digitate L.): the need for better conservation strategies. Afr J Ecol 49: 234 - 245.

Sourabh, P.; Thakur, J.; Priti; Sharma, P.; Uniyal, P.L. \& Pandey, A.K. 2018. Habitat Distribution Modelling for Reintroduction of Endangered Medicinal Plants - Ephedra gerardiana, Lilium polyphyllum, Crepidium acuminatum, Pittosporum eriocarpum and Skimmia anquetilia in India. Int J Environ Sci Te 44 (2): 207- 216.

Singh, P., Karthigeyan, K., Lakshminarasimhan, P. \& Dash, S.S. (2015) Endemic Vascular Plants of India. Botanical Survey of India, Kolkata, 339 pp.

Srivastava, A., Thakur, R.K., Srivastava, S., Dangwal, L.R. \& Garhwal, S., 2017. New population record of the endemic and endangered tree Pittosporum eriocarpum from Himachal Pradesh. Indian J. For. 40, $185-188$.

Stamatakis, A., 2014. RAxML version 8: A tool for phylogenetic analysis and post-analysis of large phylogenies. Bioinformatics 30, 1312-1313. https://doi.org/10.1093/bioinformatics/ btu033

Swets, J.A. 1988. Measuring the accuracy of diagnostic systems. Science 240: 1285-1293.

White T. J., Bruns T., Lee S. \& Taylor J. 1990 Amplification and direct sequencing of fungal ribosomal RNA genes for phylogenetics. In PCR Protocols: a guide to methods and applications (eds M. A. Innis, D. H. Gelfand, J. J. Sninsky and T. J. White), pp. 315-322. Academic Press, New York, USA. 